\title{
Prevention of hypotension associated with the induction dose of remifentanil in open heart surgery for low ejection fraction patients, in Kurdistan region, Iraq
}

Abstract

Background and objective: Hypotensive attacks commonly occur during induction of anesthesia and can result in irreversible ischemic damages to the vital body organs. This study aimed to assess the effect of using ephedrine at low doses in controlling hemodynamic changes induced by anesthesia.

Methods: A single centered single-blinded, prospective comparative study was conducted in Erbil cardiac center in periods between January 2018 and July 2018. A total of 150 patients with left ventricular ejection fraction $<40 \%$ and age younger than 80 years were included in this study. They were divided into three main groups; the 1st group was the placebo group, the 2nd group received ephedrine at a dose of $0.035 \mathrm{mg} / \mathrm{kg}$ body weight, and the 3rd group received ephedrine at a dose of $0.07 \mathrm{mg} / \mathrm{kg}$ body weight. Systolic blood pressure, diastolic blood pressure, mean arterial blood pressure, and heart rate were reported in three different phases; before induction, two minutes after induction, and five minutes after induction of anesthesia.

Results: In the placebo group, induction of anesthesia by $3 \mathrm{mcg} / \mathrm{Kg}$ of remifentanil significantly reduces diastolic, systolic, and mean arterial pressure with $P<0.001$. At two minutes after using ephedrine at the dose of $0.035 \mathrm{mg} / \mathrm{kg}$ in the induction of anesthesia significantly increases the diastolic, systolic, and mean arterial pressure with $P=0.002$, $<0.001$, and 0.007 , respectively, and at five minutes after induction with $P=0.02,0.03$, and 0.04 , respectively. Using ephedrine at a dose of $0.07 \mathrm{mg} / \mathrm{kg}$ induction of anesthesia was found to significantly increase the diastolic, systolic, and mean arterial pressure with $P<0.001$ for all the readings. The heart rate was not significantly affected by using remifentanil alone or in combination with ephedrine during induction of anesthesia.

Conclusion: Using ephedrine at different doses during induction of anesthesia with remifentanil in patients with low ejection fraction significantly prevents hypotensive attacks.

Keywords: Cardiac anesthesia; Open heart surgery; Low ejection fraction; Remifentanil; Ephedrine.

\section{Introduction}

Hypotensive attacks commonly occurring during induction of anesthesia can cause unpredictable organ damages. ${ }^{1,2}$ These attacks might be mild and self-limiting condition and sometimes persists to degrees that result in irreversible ischemic damages to the vital body organs. ${ }^{1,3,4}$ These ischemic changes are more likely to occurs when hypotensive attacks are due to low cardiac output, a situation in which low cardiac output fails to maintain normal body blood pressure. ${ }^{1}$ For that reason, new anesthetists conduct controlled hypotension anesthesia technique sparingly, or prefer not to conduct it at all. ${ }^{1,5}$ To identify those patients who are at increased risk of developing intraoperative hypotension, patients should be assessed preoperatively. Multiple risk factors affect the risk of having intraoperative hypotensive attacks, including hypertension, myocardial diseases, systematic diseases, hypovolemia, pregnancy, and anesthetic technique used. Hypertensive patients are

${ }^{1}$ Department of Surgery, College of Medicine, Hawler Medical University, Erbil, I raq.

* Correspondence: othmankolemen@gmail.com 
more liable to have hypotensive attacks and tissue ischemia. ${ }^{4}$ Also, anesthesia technique may contribute to the risk of having hypotensive attacks. Combining regional and general anesthesia technique increases the risk of having such attacks during operation. On the other hand, spinal and epidural techniques may be associated with reduced cardiac contractility (bradycardia) leading to reduced cardiac output which in turn increases the risk of having such attacks. ${ }^{4}$ In open heart cardiac surgeries, remifentanil is among the most commonly used opioids during induction of anesthesia. ${ }^{6}$ It is a potent opioid that characterized by causing significant hypotension and bradycardia when compared to other opioid analgesic drugs., Hemodynamically, the use of remifentanil reported to cause a reduction in vascular resistance and decrease arterial blood pressure and decreased cardiac output. ${ }^{8,9}$ In addition, other studies reported the occurrence, including asystole with the use of remifentanil. ${ }^{10}$ Nationally, no information on the prevention of hypotension associated with the induction dose of remifentanil in open heart surgery for low ejection fraction patients are available. This study aimed to assess the prophylactic effects of two different doses of ephedrine to prevent and control the occurrences of hemodynamic changes induced by the use of remifentanil In anesthesia.

\section{Methods}

A single centered single-blinded, prospective comparative study conducted in Erbil cardiac center in periods between January 2018 and July 2018. A total of 150 patients that underwent elective coronary artery bypass graft (CABG) surgery for the first time were enrolled in this study.

Inclusion criteria: Patients with reduced left ventricular function, left ventricular ejection fraction (LVEF) $<40 \%$ and age younger than 80 years were included.

Exclusion criteria: Obese patients with BMI more than $30 \mathrm{~kg} / \mathrm{m}^{2}$ and patients with uncontrolled hyper or hypotension, congestive cardiac failure, atrioventricular or left bundle branch block detected on their preoperative electrocardiogram (ECG), and patients with a pacemaker in situ were excluded. Patients with valvular heart disease, previous CABG surgery, misuse of alcohol or drugs, severe hepatic, or renal insufficiency were also excluded.

Procedure: Enrolled patients were divided into three main groups, 50 patients for each. The $1^{\text {st }}$ group was the placebo group. The $2^{\text {nd }}$ group received ephedrine at a dose of $0.035 \mathrm{mg} / \mathrm{kg}$ body weight. The $3^{\text {rd }}$ group received ephedrine at a dose of $0.07 \mathrm{mg} / \mathrm{kg}$ body weight. The mean hemodynamic indicators including systolic blood pressure (SBP), diastolic blood pressure (DBP), and mean arterial blood pressure (MAP) were calculated through using an invasive arterial catheter, and heart rate $(H R)$ were reported in three different phases. The $1^{\text {st }}$ phase (T1) was reported before the induction of anesthesia, the $2^{\text {nd }}$ phase (T2) two minutes after induction of anesthesia, and the third phase (T3) five minutes after induction of anesthesia. Induction of anesthesia was done by giving remifentanil at a dose of $3 \mathrm{mcg} / \mathrm{Kg}$ of body weight. According to the New York Heart Association classification, $54.7 \%$ of the study participants complained from marked limitation in physical activity with no symptoms only at rest (NYHA class III), and the remaining $45.3 \%$ complained from severe limitation in physical activity with symptoms even at rest (NYHA class IV).

Statistical analysis: All collected data were analyzed by using the statistical package for the social sciences (version 23). Descriptive statistics are presented as means \pm standard deviations, frequencies, and percentages. Multiple contingency tables were conducted, and appropriate statistical tests were performed, Chi-square was used for categorical variables, analysis of variance (ANOVA) was used to compare between means of the different study groups, and paired t-test was used to compare between the means 
of one group in two occasions. In all statistical analyses, the level of significance ( $P$ value) sets at $\leq 0.05$, and the results are shown as tables and/or graphs.

\section{Results}

The mean age's \pm SD of the placebo, $0.035 \mathrm{mg} / \mathrm{kg}$, and $0.07 \mathrm{mg} / \mathrm{kg}$ groups of ephedrine were $65.4 \pm 7.87$ years, $63.5 \pm 8.65$ years, and $66.3 \pm 7.81$ years respectively. The female to male ratio was $1: 1,1.5: 1$, and $1.38: 1$ in the placebo, $0.035 \mathrm{mg} / \mathrm{kg}$, and $0.07 \mathrm{mg} / \mathrm{kg}$ groups of ephedrine, respectively. Almost more than $80 \%$ of the participants were hypertensive, $64.1 \%$ diabetic, $64 \%$ hyperlipidemic, with no chronic obstructive pulmonary disease. Less than $20 \%$ of the participants were smokers (Table 1).

Table 1: Demographic and past medical profiles of study participants.

\begin{tabular}{|c|c|c|c|c|c|}
\hline Variable & $\begin{array}{l}\text { Placebo } \\
\text { group }\end{array}$ & $\begin{array}{l}\text { Ephed } \\
\text { mg/l }\end{array}$ & $\begin{array}{l}\text { rine } 0.035 \\
\text { gg group }\end{array}$ & $\begin{array}{c}\text { Ephedrine } 0.07 \mathrm{mg} / \mathrm{kg} \\
\text { group }\end{array}$ & $P$ value \\
\hline \multicolumn{6}{|l|}{ Age: } \\
\hline Mean & 65.4 & & 63.5 & 66.3 & $0.125^{*}$ \\
\hline$\pm \mathrm{SD}$ & 7.87 & & 8.65 & 7.81 & \\
\hline \multicolumn{6}{|l|}{ Gender: } \\
\hline Male & $25 \quad(50 \%)$ & 20 & $(40 \%)$ & $21 \quad(42 \%)$ & $0.566^{* *}$ \\
\hline Female & $25 \quad(50 \%)$ & & $(60 \%)$ & $29 \quad(58 \%)$ & \\
\hline F/M ratio & 01:01 & \multicolumn{2}{|c|}{$1.5: 0$} & $1.38: 0$ & \\
\hline Hypertension: & \multicolumn{3}{|l|}{$84 \%$} & & \\
\hline Yes & $49 \quad(98 \%)$ & 37 & $(74 \%)$ & $40 \quad(80 \%)$ & $0.003^{* *}$ \\
\hline No & $1 \quad(2 \%)$ & 13 & $(26 \%)$ & $10 \quad(20 \%)$ & \\
\hline Diabetes: & \multicolumn{3}{|l|}{$65 \%$} & & \\
\hline Yes & $30 \quad(60 \%)$ & 36 & $(72 \%)$ & $31 \quad(62 \%)$ & $0.404^{* *}$ \\
\hline No & $20 \quad(40 \%)$ & 14 & $(28 \%)$ & $19 \quad(38 \%)$ & \\
\hline Hyperlipidemia: & \multicolumn{3}{|l|}{$64 \%$} & & \\
\hline Yes & $29 \quad(58 \%)$ & 35 & $(70 \%)$ & $32 \quad(64 \%)$ & $0.457^{* *}$ \\
\hline No & $21 \quad(42 \%)$ & 15 & $(30 \%)$ & $18 \quad(36 \%)$ & \\
\hline COPD:*** & \multicolumn{3}{|l|}{$30 \%$} & & \\
\hline Yes & $12 \quad(24 \%)$ & 20 & $(40 \%)$ & $13 \quad(26 \%)$ & $0.163^{* *}$ \\
\hline No & $38 \quad(76 \%)$ & 30 & $(60 \%)$ & $37 \quad(74 \%)$ & \\
\hline Smoking: & $29 \%$ & & & & \\
\hline Yes & $15 \quad(30 \%)$ & 13 & $(26 \%)$ & $15 \quad(30 \%)$ & $0.877^{* *}$ \\
\hline No & $35 \quad(70 \%)$ & 37 & $(74 \%)$ & $(70 \%)$ & \\
\hline
\end{tabular}


Significant changes in systolic blood pressure among study participants were reported at different times between different study groups. Induction of anesthesia by using $3 \mathrm{mcg} / \mathrm{Kg}$ of remifentanil significantly $(P<0.001)$ decreased the systolic blood pressure at five minutes after induction. On the other hand, using ephedrine at dose $0.035 \mathrm{mg} / \mathrm{kg}$ in combination with remifentanil caused a significant increase in systolic blood pressure with $P<0.001$ and 0.03 at two and five minutes after induction, respectively. Using ephedrine at a dose of $0.07 \mathrm{mg} / \mathrm{kg}$ caused a significant increase in systolic blood pressure with $P<0.001$ at both two and five minutes after induction, respectively (Table 2). In the Placebo group, diastolic blood pressure significantly decreased at two minutes $(P=0.004)$ and five minutes $(P<0.001)$ after induction by $3 \mathrm{mcg} / \mathrm{Kg}$ remifentanil. Using ephedrine at dose $0.035 \mathrm{mg} / \mathrm{kg}$ in combination with remifentanil during induction of anesthesia caused an increase in diastolic blood pressure with significant levels of 0.002 and 0.02 at both two and five minutes after induction, respectively. Using ephedrine at dose $0.07 \mathrm{mg} / \mathrm{kg}$ caused a significant increase in diastolic blood pressure with $P<0.001$ at both two and five minutes after induction, respectively (Table 3 ).

Table 2: Effects of using ephedrine in combination with remifentanil on systolic blood pressure (SBP) during induction of anesthesia.

\begin{tabular}{|c|c|c|c|c|c|}
\hline & \multirow{2}{*}{$\begin{array}{l}1^{\text {st }} \text { phase SBP } \\
\text { before induction of } \\
\text { anesthesia (T1) }\end{array}$} & \multirow{2}{*}{$\begin{array}{l}2^{\text {nd }} \text { phase SBP } \\
2 \text { minutes after } \\
\text { induction of } \\
\text { anesthesia (T2) }\end{array}$} & \multirow{2}{*}{$\begin{array}{l}3^{\text {rd }} \text { phase SBP } \\
5 \text { minutes after } \\
\text { induction of } \\
\text { anesthesia (T3) }\end{array}$} & \multicolumn{2}{|c|}{$P$ value* } \\
\hline & & & & T1 Vs. T2 & T1 Vs. T3 \\
\hline \multicolumn{6}{|c|}{ Placebo: } \\
\hline Mean & 147.5 & 142.2 & 129 & 0.179 & $<0.001$ \\
\hline$\pm \mathrm{SD}$ & 19.48 & 19.69 & 23.49 & & \\
\hline \multicolumn{6}{|c|}{ Ephedrine $0.035 \mathrm{mg} / \mathrm{kg}$ : } \\
\hline Mean & 119.04 & 134.06 & 127.32 & $<0.001$ & 0.037 \\
\hline$\pm \mathrm{SD}$ & 15.3 & 18.72 & 23.2 & & \\
\hline \multicolumn{6}{|c|}{ Ephedrine $0.07 \mathrm{mg} . \mathrm{kg}$ : } \\
\hline Mean & 95.04 & 127.78 & 127.44 & $<0.001$ & $<0.001$ \\
\hline $\pm S D$ & 8.14 & 19.29 & 22.86 & & \\
\hline
\end{tabular}

${ }^{*}$ Calculated by paired t-test

Table 3: Effects of using ephedrine in combination with remifentanil on diastolic blood presssure (DBP) during induction of anesthesia.

\begin{tabular}{|c|c|c|c|c|c|}
\hline & \multirow{2}{*}{$\begin{array}{c}1^{\text {st }} \text { phase } \\
\text { DBP before } \\
\text { induction of } \\
\text { anesthesia (T1) }\end{array}$} & \multirow{2}{*}{$\begin{array}{l}2^{\text {nd }} \text { phase } \\
\text { DBP } 2 \text { minutes } \\
\text { after induction } \\
\text { of anesthesia (T2) }\end{array}$} & \multirow{2}{*}{$\begin{array}{c}3^{\text {rd }} \text { phase } \\
\text { DBP } 5 \text { minutes } \\
\text { after induction } \\
\text { of anesthesia (T3) }\end{array}$} & \multicolumn{2}{|c|}{$P$ value* } \\
\hline & & & & T1 Vs. T2 & T1 Vs. T3 \\
\hline \multicolumn{6}{|c|}{ Placebo: } \\
\hline Mean & 80.06 & 72.72 & 68.22 & 0.004 & $<0.001$ \\
\hline$\pm \mathrm{SD}$ & 14.95 & 9.82 & 14.77 & & \\
\hline \multicolumn{6}{|c|}{ Ephedrine $0.035 \mathrm{mg} / \mathrm{kg}$ : } \\
\hline Mean & 63.08 & 69.78 & 68.96 & 0.002 & 0.024 \\
\hline$\pm \mathrm{SD}$ & 11.94 & 9.94 & 14.22 & & \\
\hline \multicolumn{6}{|c|}{ Ephedrine 0.07 mg/kg: } \\
\hline Mean & 50.54 & 68.32 & 68.32 & $<0.001$ & $<0.001$ \\
\hline$\pm \mathrm{SD}$ & 7.67 & 10.36 & 14.48 & & \\
\hline
\end{tabular}


Themean arterial pressure was also five minutes after induction, respectively. significantly $(P<0.001)$ decreased after induction of anesthesia by $3 \mathrm{mcg} / \mathrm{Kg}$ remifentanil in the placebo group. Using ephedrine at a dose of $0.035 \mathrm{mg} / \mathrm{kg}$ in combination with remifentanil during induction of anesthesia caused an increase in mean arterial pressure with significance levels of 0.007 and 0.047 at both two and Using ephedrine at a dose of $0.07 \mathrm{mg} / \mathrm{kg}$ caused a significant increase in diastolic blood pressure with $P<0.001$ at both two and five minutes after induction, respectively (Table 4). No significant changes in heart rate were reported in the three different groups during the three different times of reporting (Table 5).

Table 4: Effects of ephedrine in combination with remifentanil on mean arterial pressure (MAP) during induction of anesthesia.

\begin{tabular}{|c|c|c|c|c|c|}
\hline & \multirow{2}{*}{$\begin{array}{c}1^{\text {st }} \text { phase } \\
\text { MAP before } \\
\text { induction of } \\
\text { anesthesia (T1) }\end{array}$} & \multirow{2}{*}{$\begin{array}{l}2^{\text {nd }} \text { phase } \\
\text { MAP } 2 \text { minutes } \\
\text { after induction } \\
\text { of anesthesia (T2) }\end{array}$} & \multirow{2}{*}{$\begin{array}{c}3^{\text {rd }} \text { phase } \\
\text { MAP } 5 \text { minutes } \\
\text { after induction } \\
\text { of anesthesia (T3) }\end{array}$} & \multicolumn{2}{|c|}{$P$ value* } \\
\hline & & & & T1 Vs. T2 & T1 Vs. T3 \\
\hline \multicolumn{6}{|c|}{ Placebo: } \\
\hline Mean & 105.64 & 95.96 & 88.98 & $<0.001$ & $<0.001$ \\
\hline$\pm \mathrm{SD}$ & 15.77 & 12.02 & 17.69 & & \\
\hline \multicolumn{6}{|c|}{ Ephedrine $0.035 \mathrm{mg} / \mathrm{kg}$ : } \\
\hline Mean & 84.38 & 91.44 & 89.58 & 0.007 & 0.047 \\
\hline$\pm \mathrm{SD}$ & 13.56 & 12.05 & 17.75 & & \\
\hline \multicolumn{6}{|c|}{ Ephedrine $0.07 \mathrm{mg} / \mathrm{kg}$ : } \\
\hline Mean & 66.82 & 88.14 & 89.04 & $<0.001$ & $<0.001$ \\
\hline $\pm S D$ & 8.39 & 12.58 & 17.75 & & \\
\hline
\end{tabular}

${ }^{*}$ Calculated by paired t-test

Table 5: Effects of using ephedrine in combination with remifentanil on heart rate (HR) during induction of anesthesia.

\begin{tabular}{|c|c|c|c|c|c|}
\hline & \multirow{2}{*}{$\begin{array}{c}1^{\text {st }} \text { phase } \\
\text { HR before } \\
\text { induction of } \\
\text { anesthesia (T1) }\end{array}$} & \multirow{2}{*}{$\begin{array}{c}2^{\text {nd }} \text { phase } \\
\text { HR } 2 \text { minutes } \\
\text { after induction } \\
\text { of anesthesia (T2) }\end{array}$} & \multirow{2}{*}{$\begin{array}{c}3^{\text {rd }} \text { phase } \\
\text { HR } 5 \text { minutes } \\
\text { after induction } \\
\text { of anesthesia (T3) }\end{array}$} & \multicolumn{2}{|c|}{$P$ value* } \\
\hline & & & & T1 Vs. T2 & T1 Vs. T3 \\
\hline \multicolumn{6}{|c|}{ Placebo: } \\
\hline Mean & 81.72 & 79 & 81.2 & 0.179 & 0.798 \\
\hline $\pm S D$ & 11.25 & 8.72 & 8.97 & & \\
\hline \multicolumn{6}{|c|}{ Ephedrine $0.035 \mathrm{mg} / \mathrm{kg}$ : } \\
\hline Mean & 83.58 & 82.38 & 81.52 & 0.552 & 0.319 \\
\hline $\pm S D$ & 11.31 & 8.66 & 9.14 & & \\
\hline \multicolumn{6}{|c|}{ Ephedrine $0.07 \mathrm{mg} / \mathrm{kg}$ : } \\
\hline Mean & 86.44 & 83.36 & 82.78 & 0.137 & 0.079 \\
\hline $\pm S D$ & 11.59 & 8.8 & 8.89 & & \\
\hline
\end{tabular}




\section{Discussion}

Remifentanil is widely used in clinical anesthesia because of its short half time. ${ }^{11}$ In comparison with other opioids, remifentanil is characterized by its severe hemodynamic effects. ${ }^{8}$ This study revealed that induction of anesthesia by using remifentanil significantly reduces systolic, diastolic, and mean arterial pressure, a finding that is consistent with findings of other studies. ${ }^{7,12,13}$ Yang et al. $^{7}$ reported a reduction in mean arterial pressure at 30 seconds after drug administration. This reduction is sustained for more than 5 min from remifentanil administration. Habib et al. $^{12}$ reported that systolic and mean arterial pressure significantly decreased after induction of anesthesia by using remifentanil. Boztas et al. $^{13}$ reported a significant reduction in systolic, diastolic, and mean arterial pressure after induction by remifentanil. On the other hand, remifentanil in this study does not significantly reduce heart rate. This finding is also reported by Habib et al. ${ }^{12}$ who reported that heart rate remains stable after induction by remifentanil, while Yang et $\mathrm{al}^{7}$ reported in their study a reduction in heart rate at 30 seconds after induction, but this reduction resolved in 1 minute after induction. This might explain why in current study heart rate remains stable and not affected. On the other hand, Boztas et al. ${ }^{13}$ reported a significant increase in heart rate during $1^{\text {st }}$ and $2^{\text {nd }}$ minutes after induction by remifentanil. These findings suggest that hypotension and bradycardia induced by using remifentanil are due to different mechanisms. $^{7}$ Extensive use of ephedrine as a premedication in anesthesia significantly prevents hemodynamic consequences during the period of anesthesia induction. ${ }^{14}$ It reduces the risk of hypotensive attacks by $14-37 \% .{ }^{15-17}$ However, at low doses, ephedrine was unable to prevent these hemodynamic changes. ${ }^{14}$ In this study, ephedrine in two different doses was able to significantly prevent hypotensive attacks and keeping heart rate stable after administration of remifentanil. This result is consistent with that of El-Tahan ${ }^{18}$ study who reported the significant ability of ephedrine in preventing hypotensive attacks but with significant tachycardia. Similarly, Michelsen et al. ${ }^{19}$ reported that ephedrine was able to prevent hypotension but with significant tachycardia. The low incidence of tachycardia in our study could be due to the use of remifentanil for induction of anesthesia, low doses of ephedrine, or method of patient selection.

\section{Conclusion}

Using ephedrine at two doses $(0.035 \mathrm{mg} /$ $\mathrm{kg}$ and $0.07 \mathrm{mg} / \mathrm{kg}$ ) in combination with $3 \mathrm{mcg} / \mathrm{Kg}$ remifentanil during induction of anesthesia in patients with low ejection fraction significantly prevent hypotensive attacks and decreases the risk of myocardial ischemia and other vital organs ischemia.

\section{Competing interests}

The author declares no competing interests.

\section{References}

1. Woerlee GM. Anesthesia and hypotension 2005-2018. (Accessed March 12, 2019, at http://www.anesthesiaweb.org/hypotension.php).

2. Epstein RH, Dexter F, Schwenk ES. Hypotension during induction of anaesthesia is neither a reliable nor a useful quality measure for comparison of anaesthetists' performance. $\mathrm{Br} \mathrm{J}$ Anaes 2017; 119(1):106-14.

3. Morris RW, Watterson LM, Westhorpe RN, Webb RK. Crisis management during anaesthesia: hypotension. Qual Saf Health Care 2005; 14(3):e11.

4. Bryant $\mathrm{H}$, Bromhead $\mathrm{H}$. Intraoperative hypotension anaesthesia tutorial of the week 148. 24th August 2009. (Accessed March 12, 2019, at http://www.frca.co.uk/Documents/148\% 20Intraoperative\%20hypotension.pdf).

5. Barak M, Yoav L, Abu El-Naaj I. Hypotensive anesthesia versus normotensive anesthesia during major maxillofacial surgery: A review of the literature. TSWJ 2015; 2015:480728.

6. Alwardt CM, Redford D, Larson DF. General anesthesia in cardiac surgery: a review of drugs and practices. J Extra Corpor Technol 2005; 37(2):227-35.

7. Yang $Y$, Guo Q, Fu D, Wu H, Dai R. Induction of remifentanil by bradycardia and hypotension 
through distinct biochemical mechanisms. Afr J Pharm Pharmaco 2012; 6(38):2729-34.

8. Elliot P, O'Hare R, Bill KM, Phillips AS, Gibson FM, Mirakhur RK. Severe cardiovascular depression with remifentanil. Anesth Analg 2000; 91:58-61.

9. Kazmaier S, Hanekop GG, Buhre W, Weyland A, Busch T, Radke OC, et al. Myocardial consequences of remifentanil in patients with coronary artery disease. $\mathrm{Br} J$ Anaesth 2000; 84:578-83.

10. Reid JE, Mirakhur RK. Bradycardia after administration of remifentanil. Br J Anaesth 2000; 84:422-3.

11. Beers R, Camporesi E. Remifentanil update: clinical science and utility. CNS. Drugs 2004; 18:1085-104.

12. Habib AS, Parker JL, Maguire AM, Rowbotham DJ, Thompson JP. Effects of remifentanil and alfentanil on the cardiovascular responses to induction of anaesthesia and tracheal intubation in the elderly. Br J Anaesth 2002; 88(3):430-3.

13. Boztas N, Oztekin S, Ozkardes S, Akan M, Ozbilgin S, Baytok A. Effects of different doses of remifentanil on hemodynamic response to anesthesia induction in healthy elderly patients, Curr Med Res Opin2017; 33(1):85-90.

14. Masjedi M, Zand F, Kazemi AP, Hoseinipour A. Prophylactic effect of ephedrine to reduce hemodynamic changes associated with anesthesia induction with propofol and remifentanil. J Anaesthesiol Clin Pharmacol 2014; 30:217-21.

15. Macarthur A. Solving the problem of spinalinduced hypotension in obstetric anesthesia. Can J Anaesth 2002; 49:536-9.

16. Dyer RA, Reed AR, van Dyk D, Arcache MJ, Hodges O, Lombard CJ, et al. Hemodynamic effects of ephedrine, phenylephrine, and the coadministration of phenylephrine with oxytocin during spinal anesthesia for elective cesarean delivery. Anesthesiology 2009; 111:753-65.

17. Bhattarai B, Bhat SY, Upadya M. Comparison of bolus phenylephrine, ephedrine and mephentermine for maintenance of arterial pressure during spinal anesthesia in cesarean section. J Nepal Med Assoc 2010; 49:23-8.

18. El-Tahan MR. Preoperative ephedrine counters hypotension with propofol anesthesia during valve surgery: A dose dependent study. Ann Card Anaesth 2011; 14:30-40.

19. Kol IO, Kaygusuz K, Gursoy S, Cetin A, Kahramanoglu Z, Ozkan F, et al. The effects of intravenous ephedrine during spinal anesthesia for cesarean delivery: A Randomized Controlled Trial. J Korean Med Sci 2009; 24(5):883-8. 